Proc. Estonian Acad. Sci. Eng., 2002, 8, 1, 38-51

\title{
Formation of microstructure of spray-fused powder coatings
}

\author{
Priit Kulu $^{\mathrm{a}}$, Toomas Pihl ${ }^{\mathrm{b}}$, Kristi Tammjärva ${ }^{\mathrm{a}}$, and Petri Vuoristo ${ }^{\mathrm{c}}$ \\ a Department of Materials Technology, Tallinn Technical University, Ehitajate tee 5, 19086 Tallinn, \\ Estonia; pkulu@edu.ttu.ee \\ b Department of Mechatronics, Tallinn Technical University, Ehitajate tee 5, 19086 Tallinn, Estonia; \\ toomasp@staff.ttu.ee \\ c Department of Materials Science, Tampere University of Technology, P.O. Box 589, FIN-33101 \\ Tampere, Finland; petri.vuoristo@tut.fi
}

Received 26 June 2001

\begin{abstract}
The paper describes a $\mathrm{NiCrSiB}$ self-fluxing alloys based system, containing particles of tungsten carbide or those of WC-Co hardmetal from the used hardmetal as hard phase, deposited by the spray and fusion processes. Flame and laser spray fusions were used as coating technologies. The study focuses on powder composition, hard phase grain size, processes of deposition, the effect of the composition and process on the formation of the coating structure, and on the evaluation of wear resistance of coatings. We discuss the dependence of the wear resistance of spray-fused coatings on their structure and propose structure criteria for coating selection. The "double cemented" matrix structure of self-fluxing $\mathrm{NiCrSiB}$ based coatings, which contain WC-Co particles, was found optimal in impact erosion wear conditions. The paper also discusses the costeffectiveness of coatings in application areas that are sensitive to the cost and which prefer composite coatings based on low cost recycled materials.
\end{abstract}

Key words: thermal spray, flame spray and fusion, laser spray and fusion, composite coatings, impact erosion, wear.

\section{INTRODUCTION}

Wear-resistant thermal spray coatings intended for sliding wear are hard but brittle. Under the impact loading conditions of wear, sensitive to fatigue sprayed hard coatings are useless. In this case, under extreme conditions of erosive wear (high hardness of abrasive and high velocity of abradant particles), composite spray-fused coatings ensure optimal properties of hardness-toughness. Such 
erosive wear occurs in different types of milling and mixing equipment, with predominant cyclic impact loading. It has been shown that under impact loading, for example, by collision milling in disintegrators $\left[{ }^{1}\right]$ or by wear in the stream of hard particles $\left[{ }^{2}\right]$, materials are exposed to notable strokes. The stresses generated in the particles to be ground or in the materials subjected to impact erosion are approximately an order higher than their strength. As a result, material fractures.

The main properties of coatings under impact erosion conditions are their low porosity and optimal hardness-toughness. With thermal spray methods, only using high-velocity spraying, minimum porosity (in the range $0-3 \%$ ) is obtainable $\left[{ }^{3}\right]$. By impact erosion with normal impact, such as under extreme conditions of erosive wear, an increase in the coating hardness causes an increase in the wear rate. Direct fracture or low-cyclic fatigue fracture are predominating mechanisms of the fracture and, as a result, abraded material is removed $\left[{ }^{4}\right]$. By oblique-impact erosion, microcutting or fatigue fracture is dominant.

To guarantee high abrasion-erosion wear resistance of coatings, a framed structure with maximum hardness and maximum hard phase content by obliqueimpact erosion and a matrix structure with optimal hardness and hard phase content by normal impact conditions should be established as their structural criteria $\left[{ }^{5}\right]$.

In the conditions of mixed wear (small, medium, and high impact angles), an optimal structure of sprayed powder coatings of a system of tungsten carbidecobalt, instead of a simple metal matrix consisting of WC, is a metallic (cobalt) matrix based structure containing particles of WC-Co hardmetal ("double cemented" matrix structure) $\left[{ }^{5}\right]$. In conventional WC-Co hardmetal coatings by abrasion-erosion direct fracture of carbides takes place. With the double cemented matrix structure, fracture toughness of the hard phase (WC-Co particles) is increased due to the ductile binder phase of the cobalt between small WC grains. Small WC particles or other secondary hard phases in the matrix increase resistance to microcutting and cyclic fatigue.

\section{EXPERIMENTS}

Materials and coating methods. As a basic component, a metallic matrix of composite coatings, commercial Ni-based self-fluxing alloy powders were used (Table 1). In the hard phase of composite coatings, hardmetal powder from used hardmetal, produced by disintegrator milling, was used. Chemical composition and granulometry of the powder is given in Table 1. A high content of iron in this hardmetal powder is due to the milling process. For comparison, WC-Co agglomerated granules of the HCST Amperit, as a hard phase of coatings, was also used. Selected powder composites for spray-fusion are given in Table 2. Hard phase content varied from 15 to $50 \%$. 
Table 1. Coating materials, their composition and hardness

\begin{tabular}{|c|c|c|c|c|}
\hline No. & Material & Composition, wt \% & $\begin{array}{c}\text { Granulometry, } \\
\mu \mathrm{m}\end{array}$ & Hardness, HV \\
\hline \multicolumn{5}{|c|}{ Matrix metal - self-fluxing alloys } \\
\hline 1. & $12494^{1)}$ & $\mathrm{NiCr} 11 \mathrm{Si} 2 \mathrm{~B} 2$ & $+60-160$ & 430 \\
\hline 2. & $12495^{1)}$ & NiCr13Si4B3 & $+60-160$ & 560 \\
\hline 3. & $12496^{1)}$ & $\mathrm{NiCr} 15 \mathrm{Si} 4.5 \mathrm{~B} 3.5$ & $+60-160$ & 930 \\
\hline 4. & Metco $16 C^{2)}$ & NiCr16Si4B4Cu3Mo2.5Fe0.5 & $+44-127$ & 60HRC \\
\hline \multicolumn{5}{|c|}{ Hard phase hardmetals } \\
\hline 5. & Desirec VK15 & WCCo14Fe8 & $+45-125$ & 1400 \\
\hline 6. & $\mathrm{WC}-\mathrm{Co}^{2)}$ & WCCo12 & $+5-45$ & 1300 \\
\hline
\end{tabular}

Table 2. Selected composite coatings and their composition, deposition techniques, porosity and hardness

\begin{tabular}{|c|c|c|c|c|}
\hline No. & Material & Deposition technique & $\begin{array}{c}\text { Porosity, } \\
\%\end{array}$ & $\begin{array}{c}\text { Hardness, } \\
\text { HV0.2 }\end{array}$ \\
\hline 7. & $12494+25 \mathrm{wt} \% \mathrm{VK} 15^{1)}$ & $\mathrm{FSF}^{3)}$ & $2-3$ & $675 / 1410^{6)}$ \\
\hline 8. & $12495+15 \mathrm{wt} \% \mathrm{VK} 15$ & FSF & $2-3$ & $775 / 1410$ \\
\hline 9. & +25 wt $\%$ VK 15 & $\mathrm{FSFF}^{4)}, \mathrm{FSF}$ & $2-3$ & $685 / 1545$ \\
\hline 10. & $+50 \mathrm{wt} \% \mathrm{VK} 15$ & FSF & $2-3$ & $735 / 1465$ \\
\hline 11. & $12496+25 \mathrm{wt} \% \mathrm{VK} 15$ & FSF & $2-3$ & $820 / 1410$ \\
\hline 12. & Metco $16 \mathrm{C}+30$ wt $\%$ VK15 & $\mathrm{LSF}^{5)}$ & 3.2 & $640 / 1300$ \\
\hline 13. & Metco $16 \mathrm{C}+30 \mathrm{wt} \% \mathrm{WC}-\mathrm{Co}^{2)}$ & LSF & 0.5 & $620 / 1300$ \\
\hline \multicolumn{5}{|c|}{$\begin{array}{l}\text { 1) Desirec VK15 (No. 5, Table 1) } \\
\text { 2) Sulzer Metco WC-Co (No. 6, Table 1) } \\
\text { 3) FSF: Flame Spray Fusion } \\
{ }^{4)} \text { FSFF: Flame Spray Furnace Fusion } \\
\text { 5) LSF: Laser Spray Fusion } \\
{ }^{6)} \text { Hardness of metal matrix/hard phase }\end{array}$} \\
\hline
\end{tabular}

The following technologies and equipment for depositing the coatings were used:

a) flame spray fusion (FSF), using Euro-Set XS-8 gas flame gun and oxyacetylene flame;

b) laser spray fusion (LSF), using continuous wave-optical fibre coupled HAAS HL 4006D Nd: YAG laser device for industrial material processing [ $\left.{ }^{6}\right]$.

By LSF, deposition velocity was $500-600 \mathrm{~mm} / \mathrm{min}$, shield gas - Ar with the flow rate $7.5 \mathrm{l} / \mathrm{min}$, powder feed $-30 \mathrm{~g} / \mathrm{min}$. Coatings were deposited on structural steel of $0.45 \% \mathrm{C}$ content as the substrate material. Thickness of the coatings ranged from 0.5 to $1 \mathrm{~mm}$. 
Determination of the chemical composition of coatings. Chemical composition of coating constituents was determined by the XRD analysis. Distribution of the elements in coatings was analysed by the mapping of basic elements $(\mathrm{W}, \mathrm{Co}$, $\mathrm{Ni}, \mathrm{Cr}$ ). As a result, the influence of the initial composition of composite powders and deposition processes on the chemical composition of coating constituents was determined.

Porosity and microhardness measurements. Porosity of spray-fused coatings was determined using image analysis programme Image Pro. Plus $\left[{ }^{7,8}\right]$. Microhardness of the coatings and their constituents was measured by microhardnessmeter Micromet 2001. Twelve to fifteen hardness measurements were taken.

Wear testing of coatings. Wear testing was conducted by a centrifugal impact erosion tester $\left[{ }^{9}\right]$. Parameters were as follows: abrasive - quartz sand of $0.1-$ $0.3 \mathrm{~mm}(1100-1200 \mathrm{HV})$, velocity of abrasive particles $80 \mathrm{~m} / \mathrm{s}$. Loss of weight was measured, volumetric wear rate per $1 \mathrm{~kg}$ of abradant $\left(\mathrm{mm}^{3} / \mathrm{kg}\right)$ and relative wear resistance were calculated. Reference material was normalized steel of $0.45 \%$ carbon content $(200 \mathrm{HV})$. Number of specimens for each wear test experiment was three.

\section{RESULTS AND DISCUSSION}

\subsection{Influence of spraying powder composition and coating technology on the coating structure and properties}

The microstructure of self-fluxing NiCrSiB alloy coatings deposited by FSF consisted of a solid solution on the basis of $\mathrm{Ni}$, eutectic from borides of $\mathrm{Ni}(\mathrm{NiB}$, $\mathrm{Ni}_{2} \mathrm{~B}$ ) and the solid solution. Coatings from powders 12495 and 12496 contained additional borides of $\mathrm{Cr}(\mathrm{CrB})$, of $\mathrm{Ni}\left(\mathrm{Ni}_{2} \mathrm{~B}\right)$, carboborides of $\mathrm{Cr}$ and $\mathrm{Ni}$, and silicides of $\mathrm{Ni}\left(\mathrm{Ni}_{3} \mathrm{Si}\right)$. Also additions of slag (oxides of $\mathrm{B}, \mathrm{Si}$ and $\mathrm{Cr}$ ) were present in the coatings. It is similar to the results given in $\left[{ }^{10}\right]$.

The structure, amount and composition of reinforcements in the metallic $\mathrm{Ni}$-based matrix depends on the fusion method. As it was shown in $\left[{ }^{11}\right]$, by fusion of $\mathrm{NiCrSiB}-(\mathrm{WC}-\mathrm{Co})$ coatings in the furnace (duration of heating about 15-20 min at $1200^{\circ} \mathrm{C}$ ), a substantial decomposition of hardmetal particles and formation of dendrites in the Ni-based matrix takes place (Figs. 1c-d).

A typical microstructure of FSF NiCrSiB self-fluxing alloy based coating, containing particles of WC-Co hardmetal, differs from the structure of furnacefused NiCrBSi-(WC-Co) coating. As it follows from the XRD analysis, Ni-based matrix (about $70 \%$ ) was additionally alloyed with tungsten and cobalt (obtained from partially dissolved hardmetal particles (Figs. $2 \mathrm{~b}$ and d, Table 3)), and consisted of small particles - reinforcements in the matrix (about 12\%). These small particles were mainly grains of WC of dissolved WC-Co hardmetal particles (Figs. 2b and d, Table 3). It was confirmed by the measurement of microhardness of different phases (Table 4). 

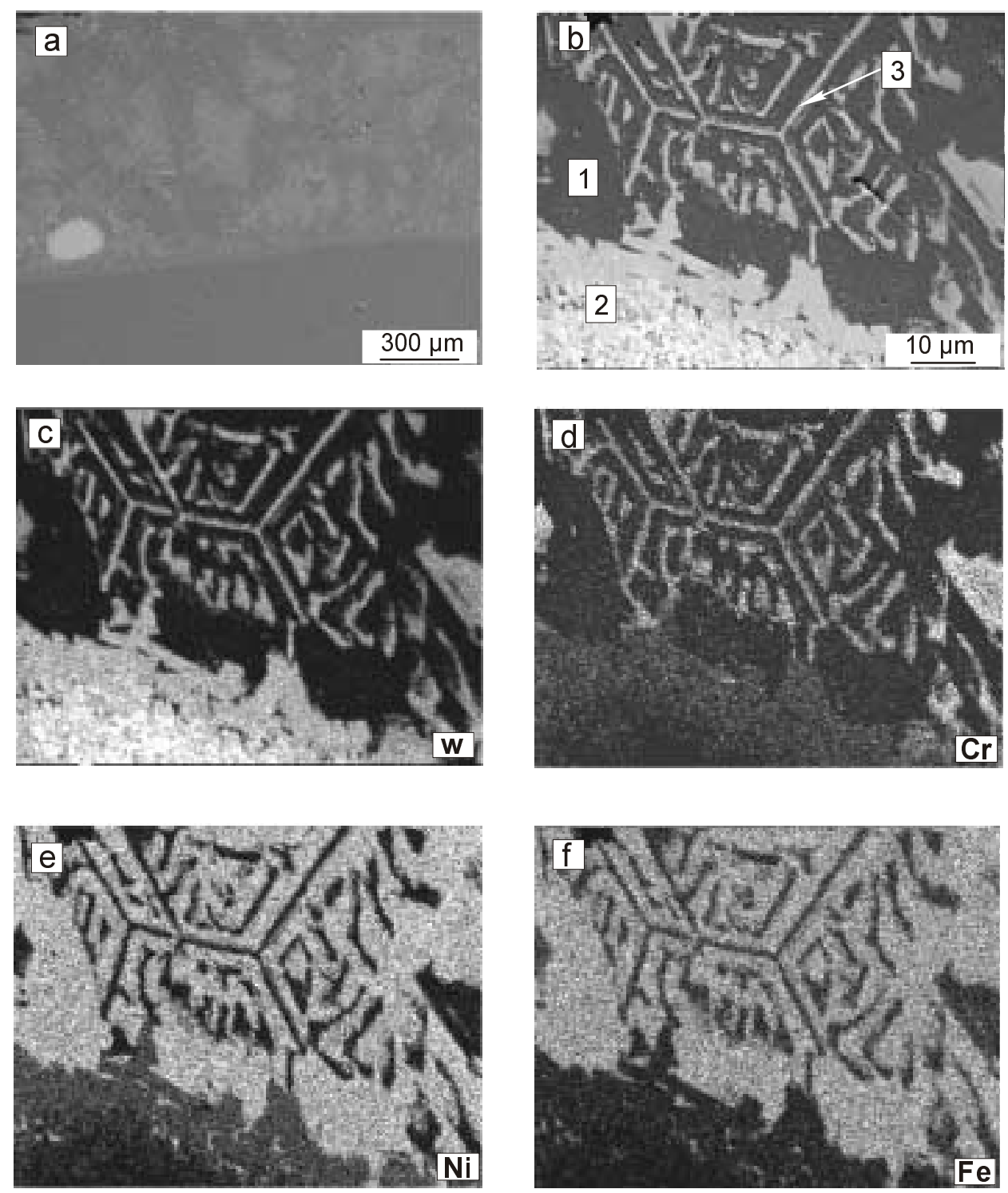

Fig. 1. Micrographs of the cross-section of FS furnace-fused NiCrSiB (12495) +25 wt \% VK15 (WC-Co) coating $(a, b)$ and distribution of elements in it (c, d, e, and f). 

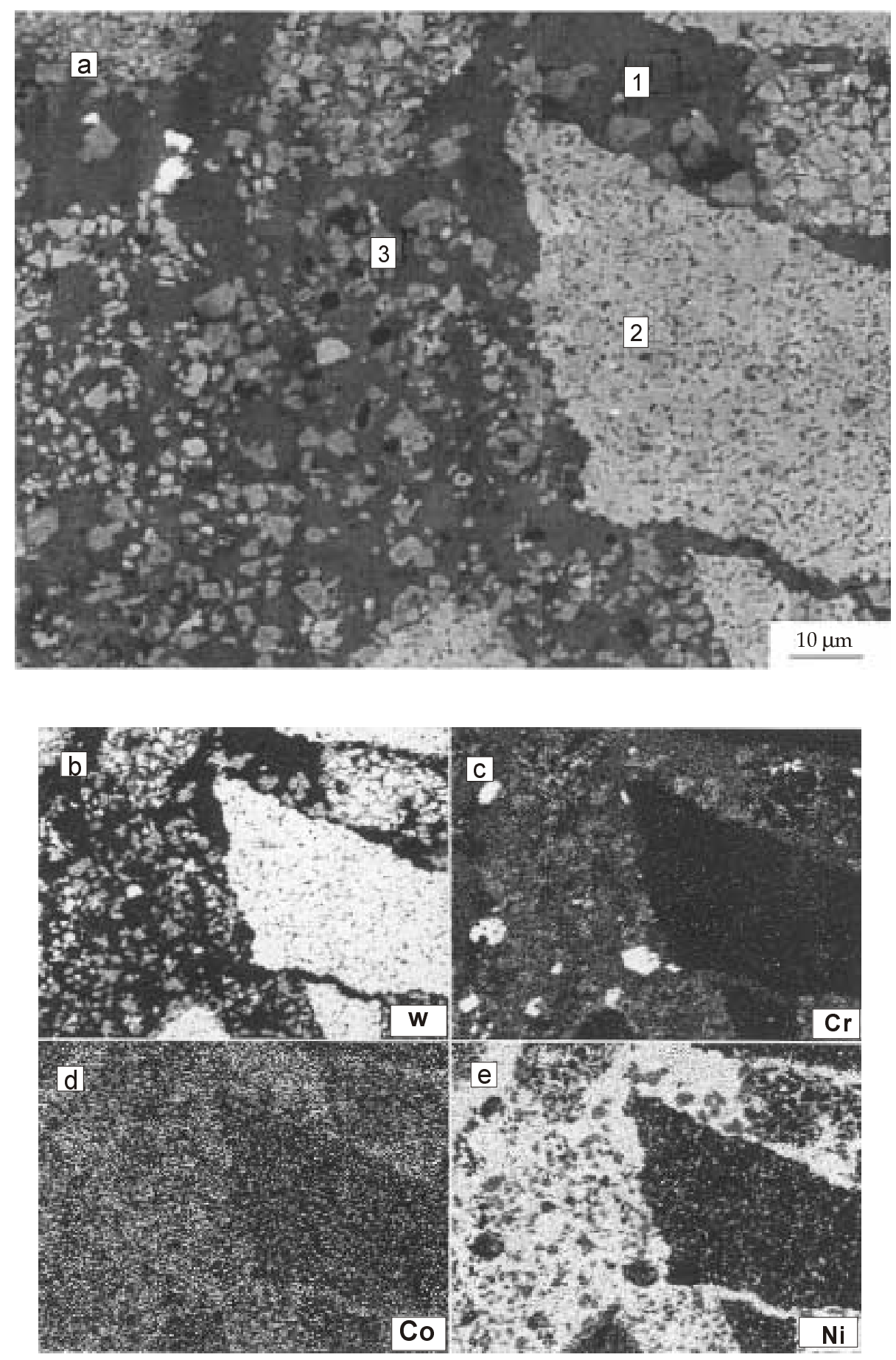

Fig. 2. Micrograph of the cross-section of FSF NiCrSiB (12495) + 25 wt \% VK15 (WC-Co) coating (a) and distribution of elements in it (b, c, d, and e). 
Table 3. Chemical composition of spray-fused $\mathrm{NiCrSiB}$ self-fluxing alloy based coatings

\begin{tabular}{|c|c|c|c|}
\hline \multirow[t]{2}{*}{ Type and coating material } & \multicolumn{3}{|c|}{ Chemical composition and vol. \% } \\
\hline & $\begin{array}{c}\text { Matrix phase } \\
\text { (No. 1, Figs. 1, 2, 3, } \\
\text { and 4) }\end{array}$ & $\begin{array}{c}\text { Hard phase } \\
\text { (No. 2, Figs. 1, 2, 3, } \\
\text { and 4) }\end{array}$ & $\begin{array}{c}\text { Reinforcements in } \\
\text { matrix (No. 3, Figs. 1, } \\
\text { 2, 3, and 4) }\end{array}$ \\
\hline FSFF & 77.0 Ni; 15.1 Cr; 3.6 Si; & $74.0 \mathrm{~W} ; 8.9 \mathrm{Co} ; 6.4$ & Dendrites $54.1 \mathrm{~W}$; \\
\hline $\mathrm{NiCrSiB}$ & $3.6 \mathrm{Fe}$ & $\mathrm{Ni} ; 4.0 \mathrm{Ti}$ & $13.1 \mathrm{Ni} ; 2.4 \mathrm{Co}$ \\
\hline$(12495)+25 \mathrm{wt} \%$ & Others: B, etc. & Others: $\mathrm{Fe}, \mathrm{C}$, etc. & Others: $\mathrm{Cr}, \mathrm{Fe}, \mathrm{C}$, etc. \\
\hline \multirow{4}{*}{$\begin{array}{l}\text { FSF } \\
\text { NiCrSiB } \\
(12495)+25 \text { wt } \% \\
\text { WC-Co (VK15) }\end{array}$} & & & \\
\hline & $42.8 \mathrm{Ni} ; 26.8 \mathrm{Fe}$ & $74.0 \mathrm{~W} ; 8.9 \mathrm{Co}$ & WC particles \\
\hline & $13.8 \mathrm{Cr} ; 4.2 \mathrm{Co}$ & $6.4 \mathrm{Ni} ; 4.0 \mathrm{Ti}$ & $\begin{array}{l}55.0 \mathrm{~W} ; 20.0 \mathrm{Co} \\
8.0 \mathrm{Ni} ; 7.0 \mathrm{Mo}\end{array}$ \\
\hline & $\begin{array}{l}\text { Others: } \mathrm{W}, \mathrm{C} \text {, etc. } \\
71 \%\end{array}$ & $\begin{array}{l}\text { Others: } \mathrm{Fe}, \mathrm{C} \text {, etc. } \\
17 \%\end{array}$ & $\begin{array}{l}\text { Others: } \mathrm{Fe}, \mathrm{C} \text {, etc. } \\
12 \%\end{array}$ \\
\hline \multirow{3}{*}{$\begin{array}{l}\text { LSF } \\
\text { NiCrSiB } \\
\text { (Metco 16C) + } 30 \text { wt \% } \\
\text { WC-Co (VK15) }\end{array}$} & $60.0 \mathrm{Ni} ; 22.0 \mathrm{Fe}$ & $74.0 \mathrm{~W} ; 8.9 \mathrm{Co}$ & Dendrites \\
\hline & $5.5 \mathrm{Cr} ; 5.0 \mathrm{Co}$ & $6.4 \mathrm{Ni} ; 4.0 \mathrm{Ti}$ & $\begin{array}{l}55.0 \mathrm{~W} ; 20.0 \mathrm{Co} \\
8.0 \mathrm{Ni} ; 7.0 \mathrm{Mo}\end{array}$ \\
\hline & $\begin{array}{l}\text { Others: } \mathrm{Si}, \mathrm{Fe}, \text { etc. } \\
73 \%\end{array}$ & $\begin{array}{l}\text { Others: Fe, C, etc. } \\
18 \%\end{array}$ & $\begin{array}{l}\text { Others: } \mathrm{Fe}, \mathrm{C} \text {, etc. } \\
9 \%\end{array}$ \\
\hline LSF & $70.1 \mathrm{Ni} ; 9.0 \mathrm{Cr}$ & $78.0 \mathrm{~W} ; 12.0 \mathrm{Co}$ & Dendrites \\
\hline $\mathrm{NiCrSiB}$ & 7.0 Co; $4.0 \mathrm{Si}$ & & $61.0 \mathrm{~W} ; 14.0 \mathrm{Ni}$ \\
\hline$($ Metco 16C) +30 wt \% & 3.0 Fe; $3.0 \mathrm{Cu}$ & & 13.0 Cr; $10.0 \mathrm{Mo}$ \\
\hline WC-Co (Metco) & $\begin{array}{l}\text { Others: } \mathrm{W}, \mathrm{Mo} \text {, etc. } \\
61 \%\end{array}$ & $\begin{array}{l}\text { Other: C } \\
18 \%\end{array}$ & $\begin{array}{l}\text { Others: } \mathrm{Fe}, \mathrm{C} \text {, etc. } \\
21 \%\end{array}$ \\
\hline
\end{tabular}

Table 4. Hardness of different phases of NiCrSiB (12495) + 25 wt \% WC-Co (VK15) (No. 9) spray-fused coatings

\begin{tabular}{lcc}
\hline \multicolumn{1}{c|}{ Phase } & No. of phase (see Figs. 1-4) & HV 0.05 \\
\hline $\begin{array}{l}\text { Ni-based metallic matrix } \\
\begin{array}{l}\text { WC-Co hardmetal particles } \\
\text { Reinforcements in matrix } \\
\text { dendrites } \\
\text { carbides }\end{array}\end{array}$ 1 (Figs. 1b, 2a, 3b, 4b) & $400-450$ \\
& 2 (Figs. 1b, 2a, 3b, 4b) & $1100-1200$ \\
& (Figs. 1b, 3b, 4b) & $380-450$ \\
& (Fig. 2a) & $1400-1450$
\end{tabular}

With LSF coatings, the microstructure (Figs. 3a and b) differed slightly from the structure of an analogous FSF coating. The amount of WC-Co particles was about $20 \%$ (Table 3 ) and the amount of reinforcements in the matrix was lower (below 10\%). As it follows from the XRD analysis, the metal matrix structure is similar to the composition of FSF coatings, but the amount of micro-sized tungsten carbide (WC) particles within the metal matrix was minimal. Using agglomerated granules of WC-Co as a hard phase of the LSF coating, the small 
WC particles were not found within the Ni-based matrix and the amount of reinforcements, dendrites, was bigger (about 20\%) and its $\mathrm{Cr}$ content higher (Fig. 4, Table 3).
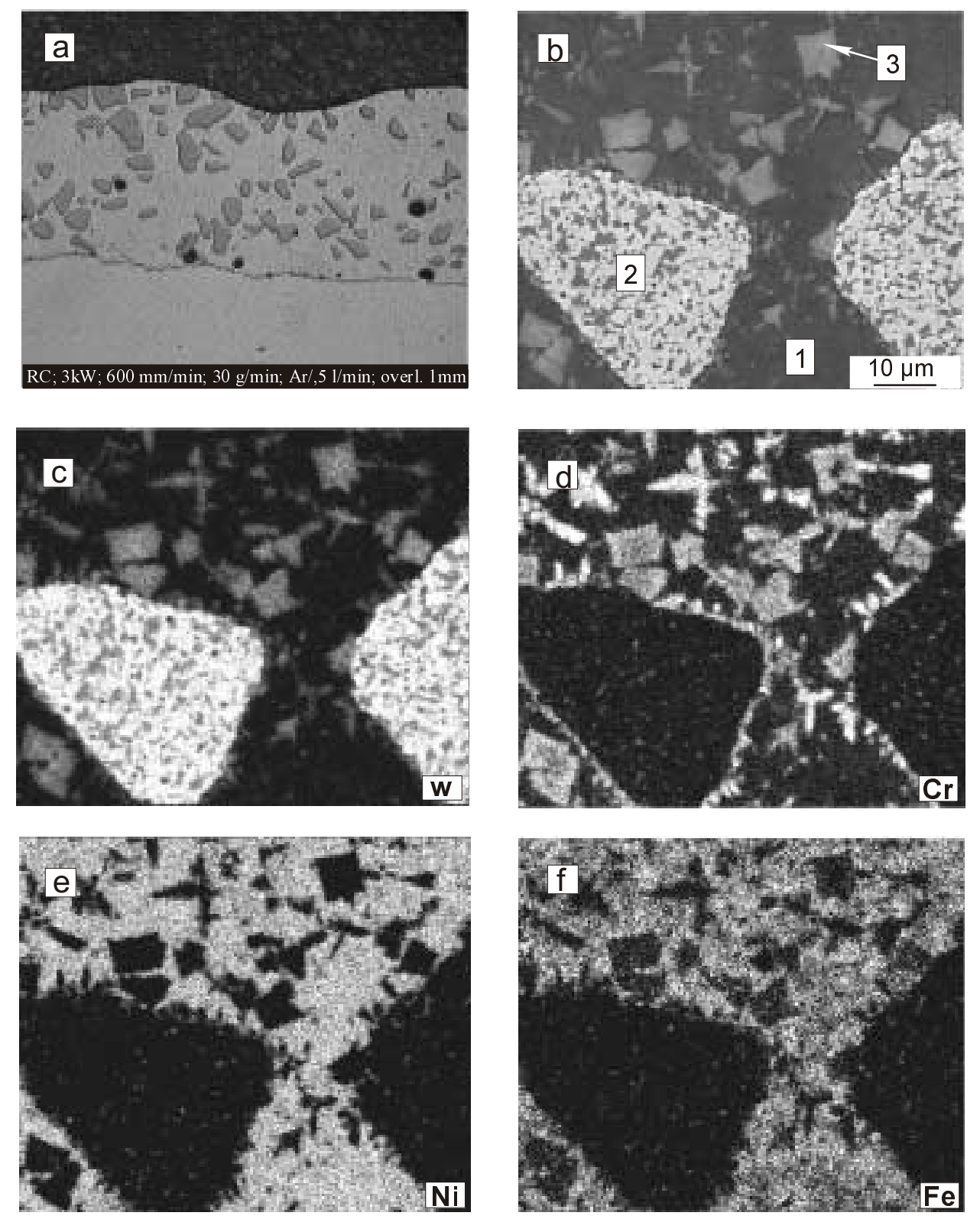

Fig. 3. Micrographs of the cross-section of LSF NiCrSiB (Metco 16C) + 30 wt \% VK15 (WC-Co) coating $(a, b)$ and distribution of elements in it (c, d, e, and f). 

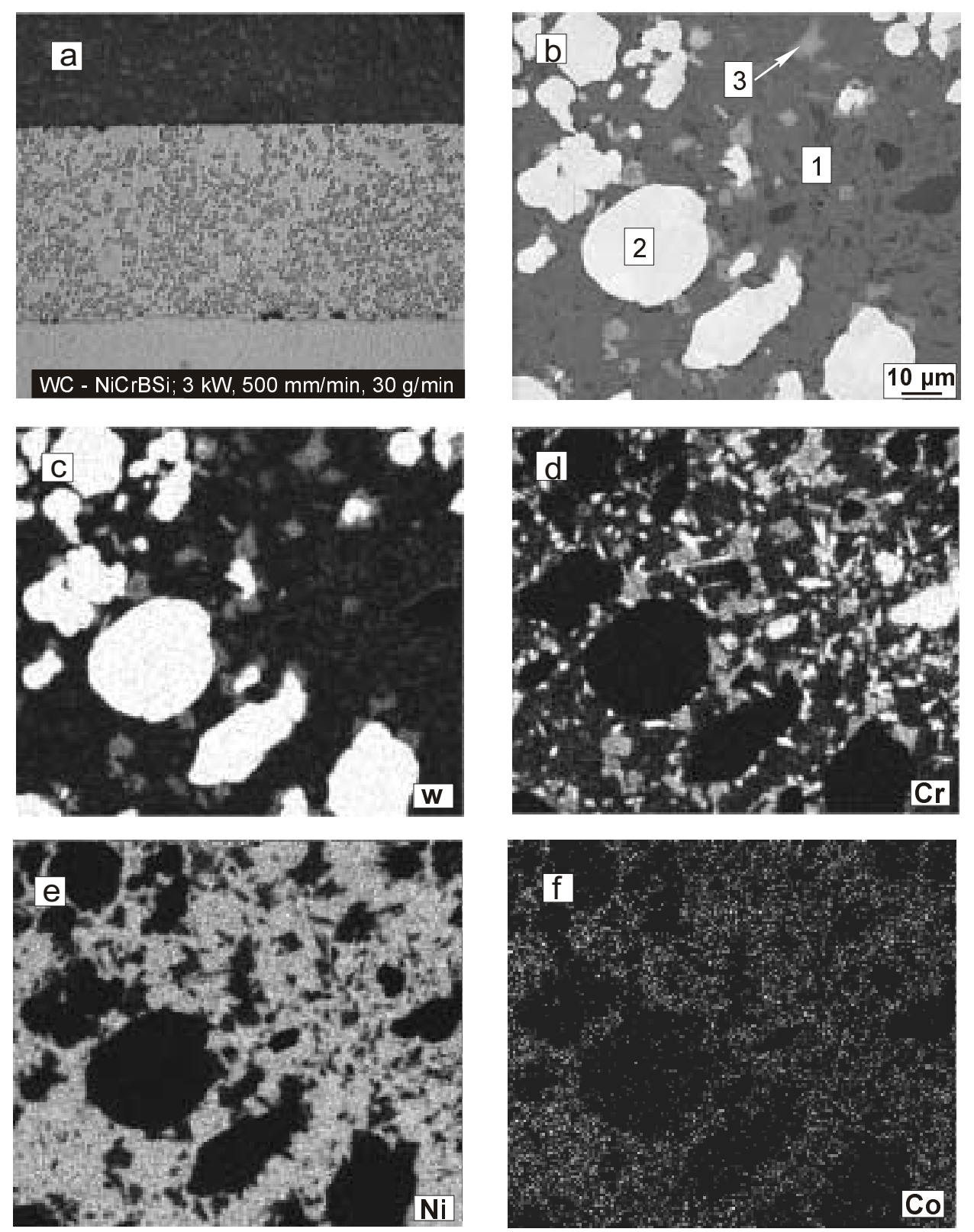

Fig. 4. Micrographs of the cross-section of LSF NiCrSiB (Metco 16C) + 30 wt \% (WC-Co) coating $(a, b)$ and distribution of elements in it (c, d, e, and f).

The difference in wear resistance of coatings from self-fluxing Ni-base alloys of different hardness was up two times, as shown in Table 5 and in $\left[{ }^{12}\right]$. The effect of the NiCrSiB matrix hardness and WC-Co content on the wear resistance of composite coatings was insignificant (Fig. 5). Depending on the hardness of 
the matrix metal (Fig. 5a), NiCrSiB-(WC-15Co) coatings exhibited a higher wear rate which differed by 30 to $40 \%$, because the matrix phase hardness is higher than that of a matrix without hardmetal particles (coating base 12494 and 12495 alloys). Higher hardness is attributed to dissolved hardmetal particles within the Ni-base matrix. In practice, microhardness of different Ni-base matrices with dissolved hardmetal micro-sized particles varied slightly (Table 2).

Table 5. Relative abrasion-erosive wear resistance of unreinforced coatings

\begin{tabular}{c|c|c|c}
\hline \multirow{2}{*}{ Coating code } & Hardness HV & \multicolumn{2}{|c}{ Relative volume wear resistance $E_{v}$} \\
\cline { 3 - 4 } & & $\alpha=30^{\circ}$ & $\alpha=90^{\circ}$ \\
\hline \multirow{2}{*}{12494} & 430 & 1.3 & 0.8 \\
12495 & 560 & 1.3 & 0.6 \\
12496 & 930 & 1.6 & 0.4
\end{tabular}

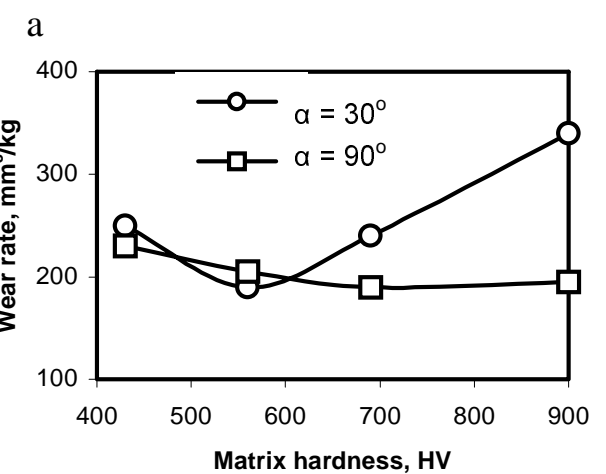

b
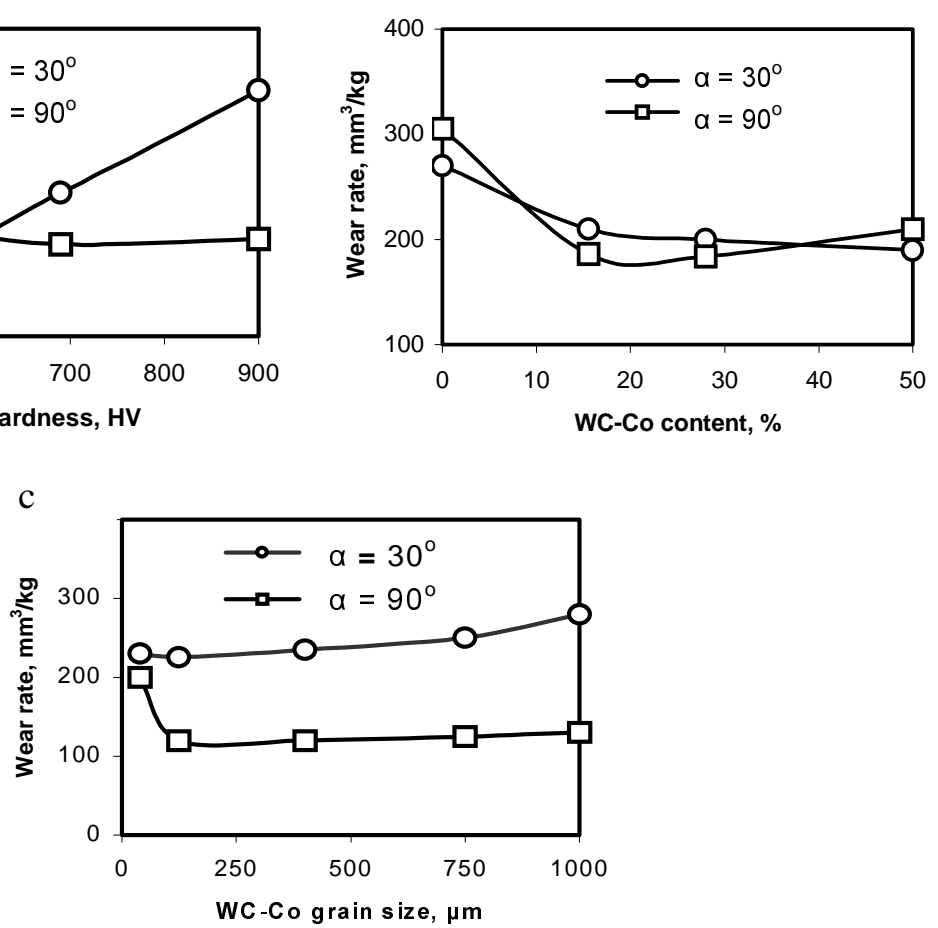

Fig. 5. Dependence of the wear resistance of FSF NiCrSiB + VK15 (WC-Co) coatings on matrix hardness (a, WC-Co content $25 \mathrm{wt} \%$ ), on hard phase content (b, matrix 12495), and on hard phase particles size (c, matrix 12495, WC-Co content 25 wt \%). 
Figures $5 b$ and $c$ show the effect of the amount of hard phase (from 15 to 50 wt $\%)$ and hard phase particle size $(+60-500 \mu \mathrm{m})$ on the wear resistance of composite coatings. According to the principles of developing abrasion-erosion resistant coatings, an increase in the amount of hardmetal particles of composite coatings led to an increase in the wear resistance under the wear conditions of oblique impact similar to sliding wear. Under operating conditions by normal impact, as a result of an increase in the hard phase content, the wear resistance of the coatings decreased.

The influence of the hard phase particle size on the wear resistance of a coating (Fig. 5c) in the range of the hardmetal particle size studied was insignificant.

\subsection{Optimal structure of coatings}

Analysis of the results of wear testing revealed a direct dependence between the wear resistance and the microstructure of materials. The wear resistance of coatings, containing WC-Co hardmetal particles, was higher than that of coatings with agglomerated WC-Co granules (Table 6).

In the case of oblique-impact erosion (by small and medium impact angles), when the wear rate decreases with an increase in the hardness and the mechanism of microcutting is dominant, a framed structure is preferred (Fig. 6a). The hard phase content must exceed 50\%. By normal impact, the matrix structure with the hard phase content lower than 50\% is preferred (Fig. 6b). By mixed impact erosion, such as in different mixing and grinding equipment, the optimal structure of WC-Co and other carbide-metal based spray-fused hardmetal coatings (instead of a simple cobalt matrix, containing particles of WC or other carbides) is cobalt (nickel) matrix based structure which contains particles of WC-Co (or other hardmetals) agglomerated granules or particles of WC-Co (or other carbides based) hardmetal $\left[{ }^{4}\right]$. It is the "double cemented hardmetal structure" (Fig. 6c). A similar structure is obtainable with hardmetal powders coated with metal (cobalt or nickel) and by the HVS method. As it was shown by experiments, another way to manufacture such complicated cemented structures is spray and fusion of composite powders based on WC-Co or other carbide

Table 6. Impact erosion wear resistance of coatings

\begin{tabular}{|c|c|c|c|c|}
\hline \multirow[t]{2}{*}{ No. } & \multirow[t]{2}{*}{ Coating material } & \multirow{2}{*}{$\begin{array}{l}\text { Method of } \\
\text { deposition }\end{array}$} & \multicolumn{2}{|c|}{ Relative wear resistance $\mathrm{E}_{\mathrm{v}}$} \\
\hline & & & $\alpha=30^{\circ}$ & $\alpha=90^{\circ}$ \\
\hline 2. & $\mathrm{NiCrSiB}(12495)$ & FSF & 1.3 & 0.6 \\
\hline 4. & $\mathrm{NiCrSiB}$ (Metco 16C) & LSF & 1.4 & 0.6 \\
\hline 9. & $\mathrm{NiCrSiB}+25$ wt $\%$ VK15 & FSF & 1.9 & 0.6 \\
\hline 12. & $\mathrm{NiCrSiB}+30$ wt $\%$ VK15 & LSF & 2.1 & 0.5 \\
\hline \multirow[t]{2}{*}{13.} & $\mathrm{NiCrSiB}+30$ wt $\%$ WC-Co & LSF & 1.6 & 0.3 \\
\hline & NiCrSiB (Tafa 1275) & HVOF & 0.6 & 0.3 \\
\hline
\end{tabular}



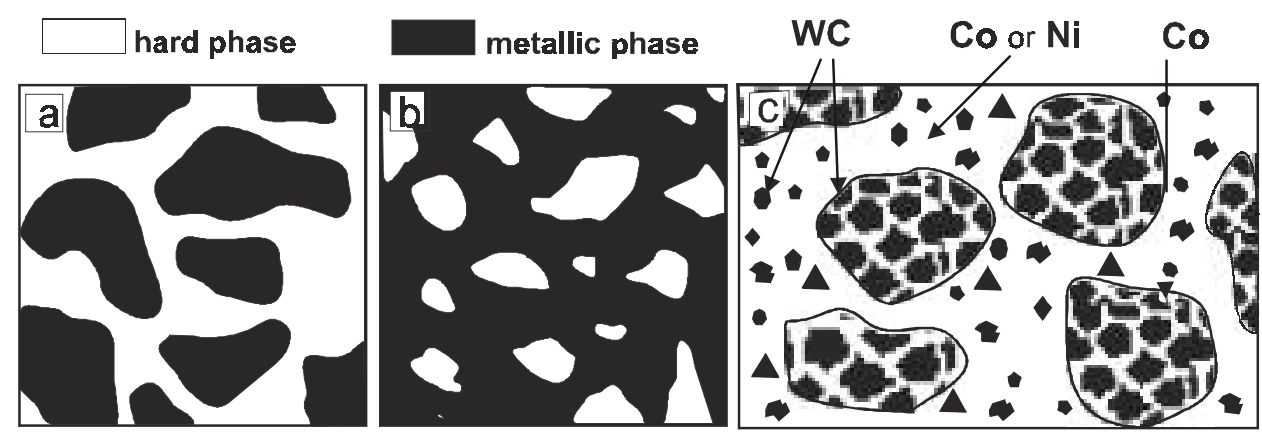

Fig. 6. Optimal structures of coatings: a-framed structure; b-matrix structure; c- "double cemented" matrix structure of a coating in impact erosion conditions.

based hardmetal powders and, for example, $\mathrm{NiCrSiB}$ self-fluxing alloy powder. The resulting structure consists of WC-Co hardmetal particles in the Ni-alloy based matrix with small dissolved tungsten carbide particles (Fig. 2a) $\left.{ }^{4,5,11}\right]$.

Similarly to normal impact erosion, direct fracture or low-cyclic fatigue fracture mechanism was predominant; as for residual stresses in coatings, compressive stresses are favourable. Such a compressive stress in coatings is obtained by HVOFspraying or by thick composite coatings manufactured by spray and fusion $\left[{ }^{11}\right]$.

\subsection{Application areas and cost-effectiveness of coatings}

In the application areas that are more sensitive to the cost factor (restoration of worn machine parts, strengthening of large areas of parts, etc.), the proposed composite powders on the basis of $\mathrm{NiCrSiB}$ self-fluxing alloy powders and recycled hardmetal powders are most attractive for thermal sprayed coatings. As it follows from Table 7, the relative cost of FSF composite NiCrSiB-(WC-Co) coatings is up to 4 times lower than that of analogous HVOF sprayed WC-Co wear-resistant coatings with similar wear-resistance characteristics.

Table 7. Cost-effectiveness of $\mathrm{NiCrSiB}-\mathrm{VK} 15$ FSF coatings ${ }^{1)}$

\begin{tabular}{|c|c|c|c|c|}
\hline Type of materials & $\begin{array}{c}\text { Cost of material }^{2)} \text {, } \\
\text { EEK }\end{array}$ & $\begin{array}{l}\text { Total cost, } \\
\text { EEK }\end{array}$ & $\begin{array}{c}\text { Relative } \\
\text { cost }\end{array}$ & $\begin{array}{l}\text { Relative wear } \\
\text { resistance in } \\
\left.\text { disintegrator }^{4}\right)\end{array}$ \\
\hline $\mathrm{NiCrSiB}$ (Castolin, 12495) & 1.2 & 3.0 & 1.0 & 1.5 \\
\hline $\mathrm{NiCrSiB}+25 \mathrm{wt} \% \mathrm{VK} 15$ & $1.2(0.9+0.3)$ & 3.2 & 1.1 & 2.5 \\
\hline WC-17Co $(\text { Tafa } 1343)^{3)}$ & 4.4 & $11-12$ & 4.0 & 3.0 \\
\hline $\mathrm{NiCrSiB}(\text { Tafa } 1275)^{3)}$ & 1.2 & 4.5 & 1.5 & 1.5 \\
\hline
\end{tabular}

${ }^{1)}$ Basis of calculation: coating with area $1 \mathrm{~cm}^{2}$ of $1 \mathrm{~mm}$ thickness

2) On the basis of prices of powders of Castolin SA and Tafa Inc.; calculated price of recycled hardmetal powder is in the range of 700-800 EEK/kg

3) For comparison: HVOF sprayed (Machine Mounted System Tafa JP5000)

4) Results of comparison testing in disintegrator DESI; treated material - quartz sand (1100 $1200 \mathrm{HV}$ ); reference material - low carbon steel of $0.45 \% \mathrm{C}$ 


\section{CONCLUSIONS}

1. New composite spraying powders and coatings on the basis of $\mathrm{NiCrSiB}$ self-fluxing alloy powder and recycled hardmetal powder intended for deposition by the spray-fusion method have been proposed.

2 . The influence of spraying powder composition and spray-fusion methods on the structure and properties of fused composite coatings has been determined. FSF enabled us to produce $\mathrm{NiCrSiB}$ alloy based composite coatings containing WC-Co hardmetal particles in dispersion-strengthened with WC and dendrites Ni-based matrix, the "double cemented" matrix structure.

3. In terms of high-impact erosion wear resistance, an optimal coating structure gave high wear resistance under mixed wear (impact angles range from 0 to $90^{\circ}$ ). Relative wear resistance was up to 2-3 times higher than that of the pure $\mathrm{NiCrSiB}$ coating.

4. The cost-effectiveness of the proposed composite powders and coatings based on them has been demonstrated. The potential application areas, more sensitive to the cost, such as restoration of worn parts, strengthening of rapidly wearing large parts of earth-removing machines, etc., are recommended.

\section{ACKNOWLEDGEMENTS}

The authors are grateful to the Estonian Science Foundation for providing funding for this work under grants Nos. 4849 and 4864 and would like to acknowledge the Tampere University of Technology for the possibility given to $\mathrm{K}$. Tammjärv for conducting laser spray fusion of coatings and a study of their properties.

\section{REFERENCES}

1. Tymanok, A. and Kulu, P. Treatment of different materials by disintegrator systems. Proc. Estonian Acad. Sci. Eng., 1999, 5, 222-242.

2. Kallas, P., Kulu, P., Pirso, Y., and Tümanok, A. Mechanisms of fracture of PM coatings by impact loading. In Proc. International Conference "Deformation and Fracture in Structural PM Materials”. High Tatras, 1996, 199-209.

3. Kulu, P. and Veinthal, R. Wear resistance of high velocity thermal sprayed coatings. In Proc. 9th Nordic Symposium on Tribology NORDTRIB 2000. Espoo, 2000, 1, 87-95.

4. Kulu, P., Veinthal, R., Kõo, J., and Lille, H. Mechanism of abrasion-erosion wear of thermal sprayed coatings. In Book of EUROMAT 2000: Advances in Mechanical Behaviour, Plasticity and Damage. Elsevier, 2000, 651-656.

5. Kulu, P. Selection of powder coatings for extreme erosion wear conditions. In Book of EUROMAT 2001. Rimini. Forthcoming.

6. Tuominen, I., Vuoristo, P., Kylmälahti, M., Mäntyla, T., Vihinen, J., and Andersson, P. H. Properties of nickel superalloy coatings as-sprayed and with Nd-YAG laser remelted. In Proc. International Thermal Spray Conference. Montreal, 2000, 180-194.

7. Image-Pro Plus 3.0. Start-up Guide. Media Cybernetics, USA, 1996. 
8. Kulu, P., Tümanok, A., Mikli, V., Käerdi, H., Kohutek, I., and Besterci, M. Possibilities of evaluation of powder particle granulometry and morphology by image analysis. Proc. Estonian Acad. Sci. Eng., 1998, 4, 3-17.

9. Kleis, I. R. Centrifugal accelerator CUK-3M for determination of wear resistance of materials by abrasion-erosion. Trans. Tallinn Polytechnical Institute, Ser. A (No. 294), Tallinn, 1970, 23-33 (in Russian).

10. Borisov, Y. S., Gorbatov, I. N., and Kalinovskij, V. R. Technology and structure of Ni-Cr-B-Sialloy based gas-thermal coatings. Zh. poroshk. metall., 1985, 19, 22-26 (in Russian).

11. Pihl, T. and Kulu, P. Influence of the technology to the properties of gas-flame coatings. In Proc. III National DAAAM Conference in Estonia. Tallinn, 1998, 118-120.

12. Kulu, P. and Halling, J. Recycled hard metal-base wear-resistant composite coatings. J. Thermal Spray Technol., 1998, 7, 173-178.

\section{Pihustus-sulatuspinnete struktuur ja omadused}

\section{Priit Kulu, Toomas Pihl, Kristi Tammjärv ja Petri Vuoristo}

On vaadeldud iseräbustuvatel nikli-, kroomi-, räni- ja boorisulamitel baseeruvaid ning kõvafaasina volframkarbiidi või kasutatud volframkarbiidsest kõvasulamist pulbriosakesi sisaldavaid pihustamise ja järgneva sulatamise teel valmistatud pindeid. Pindamismoodustena kasutati leek- ja laserpihustussulatust. Põhitähelepanu pühendati komposiitpulbrite koostisele, kõvafaasi osiste suurusele ja pindamismoodustele ning pulbrite koostise ja pindamistehnoloogia mõjule pinde struktuuri formeerimisel ning pinde kulumiskindlusele. Vaadeldi pihustussulatuspinnete struktuuri mõju pinnete kulumiskindlusele ning pinnete valiku kriteeriumeid. Optimaalse struktuuriga pinneteks löökerosioonkulumise korral osutusid volframkarbiidkõvasulami osistega armeeritud iseräbustuvate niklisulamite baasil valmistatud nn topelttsementeeritud maatriksstruktuuriga pinded. Parimate pinnete kulumiskindlus löökerosiooni tingimustes kalderosioonil ületab etalonmaterjali - süsinikterase - kulumiskindlust 2-3 korda. On käsitletud ka nikli baasil valmistatud iseräbustuvate sulamite pulbrite ja odava teisese kõvasulampulbri baasil valmistatud pihustus-sulatuspinnete majanduslikku efektiivsust sellises hinnatundlikus valdkonnas nagu kulunud detailide taastamine. 